\title{
BART and the Victoria Line: A Comparison of New Commuter Transport in California and London
}

\author{
John Grifith* and Dallas Holmes***
}

Fvolution of THE MODERN MEtropolis with its attendant suburbia $\mathrm{C}$ has created the problem of moving persons into, through, and out of these huge municipal complexes. ${ }^{1}$ Because private transportation has not proved equal to the task, the commuting problem has fallen to public authorities for solution. However, these public authorities have been ordered to establish comprehensive mass transit systems without interfering with existing governmental spheres of authority or with private sectors of the economy.

This Article is an introduction to the ways in which two cities-San Francisco and London-have approached the problem of commuter transportation. In particular, comparison will be made between the administrative and legal structures these cities have employed in making decisions about mass transportation. Hopefully, such analysis will also illuminate general problems inherent in thrusts toward regional government.

Part I, with a historical description of the Bay Area Rapid Transit District (BART), introduces a discussion in Part II of the regional government of BART; Parts III and IV, in turn, make parallel discussion of the history and government of London rapid transit (the Victoria Line). Finally, after comparison of the two systems, some tentative conclusions will be drawn. This essay is not intended as a comprehensive analysis of either BART or the Victoria Line, but rather as a comparative study of the two systems for the limited purpose of casting light on the problems of metropolitan rapid transit.

I

HISTORY OF THE BAY AREA RAPID TRANSIT SYSTEM

\section{A. San Francisco Bay Area Metropolitan Rapid Transit District Act of 1949}

The history of the Bay Area rapid transit system for present purposes begins in 1949 when the California legislature passed the San Francisco

*LL.B., 1940; LL.M., 1948. Professor of English Law, London School of Economics.

**A.B., 1962, Pomona College; M.Sc. (Econ.), 1964, London School of Economics, J.D., 1967, University of California School of Law, Berkeley.

1 "In 1960 more than 125 million people were living in the cities and suburbs of the United States. Each year urban America is spreading at the rate of a million acres-an area as large as the state of Rhode Island. In the past decade and a half, the growth of urbaniza780 
Bay Area Metropolitan Rapid Transit District Act. ${ }^{2}$ The purpose of the Act was to implement the declared policy of the State of California of stimulating maximum use of San Francisco harbor to promote domestic and international trade. As the Act recited, the geographical peculiarities of the Bay, which make it one of the finest harbors in the world, prevent full utilization of the harbor by constituting physical barriers to effective transportation of persons between various portions of the metropolitan area surrounding the Bay. As a solution, the Act contemplated the development of a rapid transit system. ${ }^{3}$

According to the 1949 Rapid Transit Act, a specially created district was needed to operate effectively in the context of multiple Bay Area governmental units. Therefore, to insure the necessary rapid transit system, it enabled the establishment of the San Francisco Bay Metropolitan Area Rapid Transit District. The Act provided that the District "shall include" the City and County of San Francisco and the cities of Alameda, Albany, Berkeley, Emeryville, Hayward, Oakland, Piedmont, and San Leandro, and "may include" all or any part of Marin, Sonoma, Napa, Solano, Contra Costa, Alameda, San Mateo, and Santa Clara Counties and any city situated therein. Altogether, over seventy county, city and county, and city governments were potentially involved.

A county board of supervisors desiring to join in forming the District was required to hold a public hearing to consider objections to joining the District. In resolving to form the District, the county board could delineate that part of its territory to be included or excluded. Elections were to follow in each county within the proposed District to determine whether the District should be formed. Eacli county was to report the election results separately for eacli city and unincorporated area within its boundaries. If a majority of the votes cast in the City and County of San Francisco and a majority of votes cast in eacli of the cities listed above favored the formation of the District, the Secretary of State was to declare the District formed. Althougl counties which approved formation of the District were to be included, cities and unincorporated areas within those counties which failed to approve the District were to be excluded.

After the formation of the District, a council was to be appointed consisting of one representative from eacl governmental unit included. ${ }^{4}$

tion las been equivalent to duplicating the populations of metropolitan New York, Detroit, Los Angeles, Chicago, and Pliladelphia." W. Owen, The Metropolitan Transportation Problear I (rev. ed. 1966).

2 Cl. 1239, [1949] Cal. Stats. 2173.

3 It defined rapid transit as the transportation of passengers by means of rail, monorail, or similar means, upon, above, or below the surface of land or water, and for the most part separated from intersecting traffic. $I d$. § $3(\mathrm{~b})$, at 2174 .

4 Each city with a population of 200,000 would liave one extra representative for each additional 200,000 persons or fraction thereof. 
- Members of the council were to be appointed for four years but could be removed at any time by their parent bodies.

The Act then itemized the powers of the District. These included the power to provide rapid transit facilities, the power of eminent domain, the power to acquire and construct all necessary facilities, to fix rates and fares, and to borrow money and levy taxes within the limits prescribed by the Act. The powers of the District were normally exercisable by the council or a board of management appointed by the council, consisting of five members qualified by training and experience to conduct the operation of rapid transit facilities.

The Act required the council to employ competent engineers to develop a comprehensive plan before incurring any bonded indebtedness. A special election requiring a two-thirds majority was to be held for the purpose of authorizing such bonded indebtedness. If authorization was not obtained at the first election, a second election could be held within six months. Taxes could be levied to meet payments of principle and interest on the bonds.

\section{B. Preliminary Reports on the Transit Problem}

In March 1950 the Oakland City Planning Commission staff submitted a preliminary report ${ }^{5}$ to the mayors and managers of the cities in the East Bay. This report analyzed existing transportation facilities in the East Bay and criticized Key System, the local bus service. It suggested certain immediate and costly improvements in the bus service. In a cautious statement of doubtful validity, however, the report suggested that if Key System could attract sufficient additional patronage, such increased outlays might eventually lead to net gains in revenue.

The only agency with power to regulate private carriers was the State Public Utilities Commission, and the report noted that since 1945 almost all of Key System's applications to the Commission had been for cuts in services and increases in fares. Although most requests had been granted because the carrier was losing money, the result had been a natural and further decline in patronage.

The report emphasized the need for a rapid transit system on gradeseparated rights of way. ${ }^{6}$ It argued for public, rather than private, control and ownership of the system. It also urged the creation of an area-wide, special purpose district to control the system, admitting, however, that such a special district would add to the existing multiplicity of governmental units. The report spoke of the "strong possibility" that the estab-

5 Oakland City Planning Comar's Stafr, The Transit Probleam in the East Bay (1960).

6 The transit system's tracks would be separated by underpass or overpass from other rights of way (such as highways or footpaths) to avoid cross traffic over its tracks. 
hishment of a successful metropolitan transit district might lead to the solution of other area-wide problems on a similar basis.

However, since no legal machinery existed in 1950 enabling the cities of the East Bay to create a joint transit system, state legislation would be necessary. The Act of 1949 permitted the East Bay cities to form a district only if San Francisco was also included. Moreover, the report said that "the act also is unworkable in that it denies a district the power to acquire any existing transit system or to operate local feeder lines where they would compete with an existing service." Although the report concerned only the East Bay, it recognized that ultimately the East Bay, San Francisco, the Peninsula, and the counties north of the Bay should be served by a unified and coordinated regional transit network. It therefore recommended an immediate survey of the East Bay's needs as a step toward making plans for improved transit.

In April 1951 the Senate Interim Committee on the San Francisco Bay Area Metropolitan Rapid Transit Problems issued a report empliasizing the urgent need for the kind of transit system envisioned by the Act of 1949 , while noting that the area's seventy-six political subdivisions made the development of a coordinated program difficult without the guidance of some neutral leadership. ${ }^{8}$ The Committee believed that development of a rapid transit system presupposed technical, authoritative engineering studies and that the residents of the Bay Area were not ready to vote on establishing a rapid transit district because they lacked adequate information on the subject. The Committee asked the legislature to create a neutral agency to accomphish the task of providing reliable information on the transit situation.

The alternative solution of proceeding through private enterprise was rejected:

Spokesmen for these major carriers who have appeared at our committee hearings and have expressed their opinions to individual committee members hold out no hope that the existing systems can produce at their own expense a service commensurate to present needs or those of the foreseeable future.

No one to whom this committee or its members have talked believes this problem can ever be solved by private enterprise alone. All consider without question that it can be solved only with the aid of public money sufficient to establish a new and modern system designed specifically to meet present needs and those of the foreseeable future. ${ }^{9}$

7 Transit Problear IN the East Bay, supra note 5, at 42.

8 Cas. Sentate Intertac Couns. on San franctsco Bat Area Metropolitan Rapdo Transtr Problears Rep., in 1 Appendtx to the Journat of the Semate (Reg. Sess. 1951). $9 \mathrm{Id}$. at 10. 


\section{The San Francisco Bay Area Rapid Transit Commission}

In 1951 a second statute was passed, ${ }^{10}$ adding a new section 39 to the 1949 Act. It created the San Francisco Bay Area Rapid Transit Commission composed of 26 members. ${ }^{11}$ Fourteen of these members were to be appointed by the Governor, eleven were to be appointed by the nine Bay Area counties, the final member being the California State Director of Public Works.

The Rapid Transit Commission, aided by an appropriation of 50,000 dollars, was required to study the rapid transit problems in the San Francisco Bay Area. It was to aid governmental bodies in the various cities and counties in investigating their interurban and local transit needs and in combining their findings with those of other governments in the area. It was also to furnish engineering, planning and other technical assistance not otherwise available, correlate these findings, and-with the aid of qualified engineers, fiscal experts and local representatives-assist in developing a coordinated rapid transit plan. This plan was to include an estimate of construction costs and the costs of acquiring necessary lands, equipment, and facilities. The Commission was to report to the Legislature within fifteen days after the commencement of the 1953 regular session. ${ }^{12}$

The Rapid Transit Commission proceeded to collect, analyze, and correlate available plans, data, and information from research activities in the nine counties, employing the firm of Deleuw, Cather \& Co. to assist in this task. The results along with the consultant company's recommendations were summarized in a preliminary report made by the Commission to the Legislature in January $1953 .{ }^{13}$ This report analyzed the transportation needs of each of the nine counties.

In this preliminary report, the Commission concluded, first, that a satisfactory solution to the transit problem in the Bay Area could not be reached by building highways and facilities for automobile transportation alone, but could be reached only through evolving a satisfactory system of mass transit based on moving people, not cars; second, that there was an urgent need for a unified system of mass rapid transit; third, that this system should be capable of expanding to include other means of transportation not incorporated in the original system; and, finally, that the rapid transit system would have to provide a short elapsed travel time

10 Ch. 1760, [1951] Cal. Stats. 4187.

11 These members were the California State Director of Public Works, five representatives of the City and County of San Francisco, five representatives of Alameda County, three representatives of Contra Costa County, and two representatives from each of the following counties: Marin, Napa, Santa Clara, San Mateo, Solano, and Sonoma.

12 The Commission was to come to an end on December 31, 1953 unless by a two-thirds vote it resolved that public welfare and convenience required the extension of its life to a date not later than December 31, 1955.

13 San Francisco Bay Area Rapm Transit Comas's, Preimomnary Report (1953). 
between departure point and destination, modern, safe, comfortable equipment, convenient transfer facilities, frequent and convenient schedules, and adequate, convenient, low-cost (preferably free) parking facilities at suburban stations.

The Commission also found that while development of a master plan required professional personnel, the planning committees did not have resources sufficient to develop such a plan. Therefore, the plan had to be developed by one central agency which could direct all necessary studies. The Rapid Transit Commission recommended four steps in developing such a master plan: first, initiate studies-including population estimates -necessary to formulate a regional economic plan; second, conduct origin and destination studies of interurban vehicular and transit passengers; third, prepare a preliminary regional transit proposal broken down into phases with construction timetables for each phase; and fourth, estimate construction costs and anticipated revenue for the initial phase of construction. The total cost of these steps was estimated to be 750,000 dollars. Development of a master plan would be the joint responsibility of the State of California and the nine Bay Area counties, and there was evidence that all nine counties would agree to share the cost. The Rapid Transit Commission offered to appoint committees from interested public and private groups to act in an advisory capacity and asked for funds to develop the master plan-400,000 dollars from the state and 350,000 dollars from the nine counties.

The Senate Interim Committee endorsed this preliminary report from the Commission, drawing particular attention to existing transportation facilities as described in the report. There were four major interurban operators serving the Bay Area: Pacific Greyhound Lines, which served all nine counties and was the sole interurban operator in Marin, Sonoma, Napa, and Solano; Key System Transit Lines, which provided local bus service in the East Bay area and some transbay service; Southern Pacific Company, which operated a steam train commuter service between San Francisco and San Jose serving San Mateo and northern Santa Clara counties; and Peerless Stages System, which provided motor coach service between Oakland and Santa Cruz via San Jose and intermediate points with a line to Palo Alto via Newark.

As these reports were being made, more and more people were utilizing automobiles. In 1952, the San Francisco Chamber of Commerce sponsored a count of persons entering or leaving San Francisco and found seventy-nine per cent using cars and only twenty-one per cent using a transit service. ${ }^{14}$ In the same twenty-four hour period, 211,323

14 In 1950, San Francisco's daytime population increased $31 \%$ more than its resident population increased. W. Owes, supra note 1, at 233. 
persons brought 120,706 cars into the city. The Interim Committee also found that mass transit was declining. Key System, for example, had applied to the California Public Utilites Commission for permission to abandon service on lines in Oakland and on the Bay Bridge; transit systems in general were raising fares to meet rising costs.

The Rapid Transit Commission had estimated that the nine counties could ultimately support 10 million people, predicting a population of 3.6 million by 1970 . This population would require forty-eight lanes of freeways by 1970 to assure adequate access to the central metropolitan area during peak hours of traffic.

The Interim Committee concluded (1) that there was an imperative need for creating an up-to-date mass rapid transit system, (2) that unless a workable master plan was devised and a rapid transit system introduced, the Bay Area would suffer economically, (3) that the nine counties agreed on the need to participate on a matching funds basis in the development of master rapid transit plans, (4) that there was a detailed and workable plan that had received the enthusiastic support of those concerned, and (5) that legislative action should be taken at once.

A third statute was accordingly passed in $1953^{15}$ appropriating 400,000 dollars to enable the Rapid Transit Commission to make preliminary studies for the development of a coordinated master plan. The purpose of this appropriation was to implement two of four recommendations made by the Commission in its preliminary report. ${ }^{16}$

The statute provided that the amount appropriated by the state was to be spent only on the condition that the nine counties first appropriated an additional 350,000 dollars to enable the Commission to carry out its other two recommendations. ${ }^{17}$ Contributions were prorated on the basis of population, the condition being fulfilled on November 4, $1953 .^{18}$

On November 12, 1953 a contract was negotiated with the engineering firm of Parsons, Brinckerhoff, Hall \& MacDonald, for the preparation of planning and engineering studies and for the formulation of a coordinated rapid transit plan to serve the needs of the Bay Area

15 Ch. 1212, [1953] Cal. Stats. 2769.

16 The relevant recommendations are (1) that the studies necessary to formulate a regional economic plan including population estimates be conducted, and (2) that origin and destination studies of interurban vehicular and transit passengers be made. Preammary REPORT, supra note 13, at 18.

17 The relevant recommendations are (1) preparation of a preliminary regional transit proposal broken down into phases with construction timetables for each phase and final preliminary plans, and (2) estimation of construction costs and anticipated revenue for the initial phase of construction.

18 The payments by the counties were: Alameda, $\$ 97,000$; Contra Costa, $\$ 39,000$; Marin, $\$ 11,000$; Napa, $\$ 6,000$; San Francisco, $\$ 100,000$; San Mateo, $\$ 31,000$; Santa Clara, $\$ 38,000$; Solano, $\$ 14,000 ;$ Sonoma, $\$ 14,000$. 
counties. The report of the engineering consultants was transmitted to the Legislature in January 1956.

In November 1954, the Rapid Transit Commission retained Stanford Research Institute (SRI) to study ways of financing capital costs of the regional rapid transit plan recommended by the engineering consultants. SRI was also asked to delineate the kind of agency which should be created to construct and operate the rapid transit system. SRI's report was transmitted to members of the Legislature in March $1956 .{ }^{10}$

In the meantime the Senate Interim Committee determined in a 1955 report $^{20}$ that the general transit situation had deteriorated. ${ }^{21}$ It referred to the expectation that the 3 milhon population of the Bay Area in 1954 was likely to rise to $4 \mathrm{x} / 2$ million by 1970 . In May 1954 , a total of 85,150 persons commuted to work daily to San Francisco, three-fifths of them by car. Such commuting was expected to increase relentlessly. "Those who have long argued," said the Committee, "that the Bay area is a single economic and social unit saw proof in this restless movement that the Bay area resident thinks and acts as if the entire region is his home."22 The Committee reaffirmed its conviction that:

[T] he way to combat traffic and parking congestion, uneconomic public transportation, and growing paralysis of surface communications is to let no side issues, no purely local difficulties stand in the way of a unified

19 F. Alren \& M. Sibbett, Organizationad and Financtal Aspects of the Proposed San Francisco Bay Area Rapid Transtr System (Stanford Research Institute, 1956).

20 Senate Intermar Comar. on San Franctsco Bay Area Metropolitan Rapid Transit Problears, Moving People (1955).

21 On July 24, 1953, a strike paralyzed Key System for seventy-six days. The California Public Utilities Commission refused to grant permission to Key System to abandon its train service on "A" and "B" transbay lines. In January 1954, the Public Utilities Commission announced that the city-owned Municipal Railway, which had been losing about $\$ 1,000,000$ a year for the past seven years, would lose $\$ 4,000,000$ in 1954-55. Cable car service was curtailed in San Francisco and bus and streetear routes were cut throughout the city.

The next month Key System applied to the Commission for permission to cut services further. This was granted whereupon Key System announced that it contemplated still more curtailments and asked for tax relief of $\$ 188,000$ per year. In April 1954, Pacific Greyhound revealed that its buses laad lost $\$ 234,000$ in Marin County in 1953 and asked for increases of $63 \%$ to $120 \%$ on North Bay commuter fares. In July, Key System served public notice that it intended to abandon all transbay trains and substitute coaches within one or two years. In August, Southern Pacific applied for increases on comnuuter fares. In October, Key System was allowed by the Public Utilities Commission to curtail services on the East Bay motor coach lines and to increase fares. In November, Pacific Greyhound was granted fare increases averaging almost one-third on its North Bay service, and in December applied for an increase in fares on the Peninsula bus service averaging $49 \%$ and ranging from $15 \%$ to $77 \%$. In January 1955 , Key System applied to abandon all its rail services, and a rapid transit district was created in the East Bay to replace it. Moving Peopre, supra note 20 , at $7-9$.

22 Id. at 9. 
mass transit system linking the Bay area counties into a single economic and geographic entity. ${ }^{23}$

In 1955 another statute was passed. ${ }^{24}$ The life of the Rapid Transit Commission which was to expire at the end of 1955 was extended to the end of 1957. In addition, the 1955 Act provided that the Commission might expend any unallocated portion of the 400,000 dollars appropriated under the Act of 1953 or the 350,000 dollars contributed by the counties ${ }^{25}$ to disseminate full information to the public concerning the rapid transit plan.

The Rapid Transit Commission's final report was transmitted to the Legislature on December $16,1957 .^{20} \mathrm{~A}$ report by the engineering consultants had been transmitted in January $1956^{27}$ and then widely publicized and discussed. Such publicity found response in many private and public bodies, including the boards of supervisors of Alameda, Contra Costa, and Marin counties. Similar publicity and discussion followed publication of the Stanford Researcl Institute Report. The Commission, with the help of the Legislative Counsel Bureau and the Attorney General's office, prepared a legislative draft for establishing the regional agency necessary to implement the rapid transit program. This draft was also widely distributed and discussed. It was the subject of public hearings before the Senate Interim Committee in November 1956. A revised draft was introduced in the Legislature during January 1957, and copies of the printed bill ${ }^{28}$ were distributed widely. On February 20th, 1957, the Senate Interim Committee held a public liearing on the bill. When the Legislature reconvened in March 1957, the bill was brought up for consideration and, after amendment, enacted. ${ }^{29}$

The Rapid Transit Commission recommended in its final report ${ }^{30}$ that a unified, long-range program of mass rapid transit construction and operation be undertaken in the Bay Area and that the facilities provided conform generally to those recommended by the engineering consultants. It urged the Rapid Transit District created by the Act of 1957 to initiate the rapid transit program and to embark on a comprehensive public information campaign. With some other friendly advice, the Commission

23 Id. at 5 .

24 Ch. 1319, [1955] Cal. Stats. 2401.

25 However, the counties had to consent to this expenditure of their money. Sce note 18 supra.

26 San Francisco Bay Area Rapt Transit Compm's, Report to the Legtslature or the State or CaLIForNia (1957).

27 Parsons, Brinckerhoff, Halt \& MacDonatd, Regionat Raptd Transit, A Report to the San Francisco Bay Area Rapid Transit Commo'n (1956).

28 S.B. 850, Cal. Reg. Sess. (1957).

29 Ch. 1056, [1957] Cal. Stats. 2291.

30 See note 26 supra. 
declared that its duties, undertaken six years before, had been discharged. The Commission was dead. Long live the District!

II

THE BAY AREA RAPM TRANSIT DISTRICT

When created by the State Legislature on June $4,1957,31$ the San Francisco Bay Area Rapid Transit District (BART) comprised territory within five counties: Alameda, Contra Costa, Marin, San Francisco, and San Mateo $^{32}$ As a regional public agency the District was given the responsibility of building and operating "a rapid transit system for the transportation of passengers and their incidental baggage,"33 a deceptively simple sounding mandate.

\section{A. District Board of Directors}

The governmental functions of the District were vested in a Board of Directors..$^{34}$ Members of the Board were to be appointed by mayors, ${ }^{35}$ city councilmen, ${ }^{36}$ and county supervisors ${ }^{37}$ within the District. To be appointed, members needed no more specialized qualifications than to be a resident and registered to vote in the county which they represented ${ }^{38}$ and to be willing to serve a four-year term ${ }^{39}$ for less than lucrative compensation. ${ }^{40}$

31 CAL. PUb. UTIL. Code $\$ \$ 28500-29,28757$ (West 1965).

32 Id. \$ 28600. See notes 63-69 infra and accompanying text for an account of the later withdrawal of Marin and San Mateo counties from the District. Other counties can be annexed by the District, $i d$. $\$ \$ 29500-80$, including those counties specifically inentioned in $\$$ 28602 (Napa, Santa Clara, Solano, and Sonoma).

33 Id. $\$ 29030$. The Board of Directors currently consists of twelve members, four from each of the counties now in the District.

34 Id. § 28730.

$35 I d . \S 28700,28733$.

30 Id.

37 Id. $\S 28733$. A contemplated plan to seat local elected public officials directly on the Board of Directors was rejected upon the advice of the Calforma Attorney General that such overlapping offices could prove detrimental to the public interest. 30 OP. CAL. ATr'y Gen. 184, 185 (1957). See People ex rel. Chapman v. Rapsey, 16 Cal. 2d 636, 107 P.2d 388 (1940); People ex rel. Bagshaw v. Thompson, 55 Cal. App. 2d 147, 130 P.2d 237 (1942). The BART statute was later amended to allow county supervisors, mayors, and city councilmen to serve contemporaneously as Directors. CAL. PUB. UTII. CODE $§ 28731.5$ (West 1965).

38 Car. PUB. UTIL. Code $§ 28731$ (West 1965).

39 Id. § 28737.

40 Directors are paid $\$ 50$ for each meeting they attend, with a maximum stipend of $\$ 250$ per month. They are also reimbursed for travel and personal expenses incurred in the performance of their duties. $I d . \S 28741$. According to the District Secretary, these expense reimbursements average less than $\$ 100$ per month per director. Interview with $R$. L. Shephard, Secretary of the Bay Area Rapid Transit District in San Francisco, Cal., May 5, 1967. 
In order to carry out the avowed purpose of the District to establish and maintain a rapid transit system for the San Francisco Bay Area, the Board has been endowed with wide powers. It may acquire, construct, or use the rights of way of, rail and bus lines, stations and platforms, yards and parking lots, "and any and all other facilities necessary or convenient for rapid transit service within or partly without the district, underground, upon, or above the ground and under, upon, or over public streets, highways, bridges, or other public ways or waterways, together with all physical structures necessary or convenient for the access of persons and vehicles thereto." ${ }^{\prime 1}$

To finance these activities the Board can, with the approval of the county boards of supervisors ${ }^{42}$ and three-fifths of the voters of the District, ${ }^{43}$ issue general obligation bonds up to the amount approved, pro- . vided that this bonded indebtedness does not exceed fifteen per cent of the assessed valuation of taxable property within the District. ${ }^{44}$ The Board may assess and collect an annual tax sufficient to pay principal and interest on these bonds and to cover service of the debt. ${ }^{45}$ The Board may levy an additional tax of five cents on each one hundred dollars of assessed valuation of taxable property within the District to cover expenses other than debt service on its general obligation bonds. This tax is designed as a supplement to the revenues expected from the operation of the transit system, and is therefore expressly himited to the actual operational requirements of the District. ${ }^{46}$ The Board may also issue bonds to be financed out of anticipated revenues. ${ }^{47}$ It may issue equipment trust certificates for the purchase of rolling stock, also to be financed out of future revenues. ${ }^{48}$ Finally, as a fifth source of funds, the Board may even issue special assessment bonds. ${ }^{49}$

Once the transit system is established, the revenues generated by its rates and service charges are to pay, "insofar as practicable," the costs of operation, repairs, depreciation, maintenance, new rolling stock, and debt

41 Cax. PUB. UTII. CODE $\S 29031$ (West 1965). The District can also lease the use of facilities to any operator upon terms it deems to be in the public interest. Id. $\S 29032$.

42 Id. $\$$ 29154-57.

43 Id. \$§ 29158-68.

44 Id. § 29150.

45 Id. $\$ \$ 29120-22$.

46 Id. § 29123. For the mechamics of assessment and collection of this tax, see id. $\$ \S 29124-31$. This tax now produces revenue of about $\$ 21 / 2$ million a year. Hearings before the Assembly Interim Comm. on Transportation and Commerce, San Diego, Cal., Jan. 12, 1966 , at 7.

47 Cat. Pub. UtrL. Code $\$ 29240$ (West 1965).

48 Id. $\S \S 29250-54$.

49 Id. § 29260. No special assessment bonds have been issued as of May 1967. 
service. ${ }^{50}$ The Board is to set ticket charges accordingly, the only statutory limitation being that the rates "shall be reasonable."

To assist in carrying out their mandate, the Board of Directors has the power to condemn property in eminent domain proceedings and otherwise acquire "real and personal property of every kind within or without the district necessary to the full or convenient exercise of its powers." ${ }^{\prime 52}$ It may also hire appropriate personnel ${ }^{53}$ and may contract for outside professional services if the work contemplated cannot be performed by District officers and employees. ${ }^{54}$

\section{B. Initial Obstacles}

\section{Money and Secession}

At its first meeting on November 14, 1957, the new Board of Directors was confronted with an impressive challenge: to utilize the broad statutory authority given them by the State of California to plan, build, and operate a inodern, speedy, convenient, and economically self-sufficient transportation system for the San Francisco Bay region. Perhaps overawed by the task the Board moved into action rather slowly; but by the end of 1959 a general manager had been selected ${ }^{55}$ initial administrative personnel had been hired, and consultants had been employed to study and report on the engineering and financing problems confronting the District. ${ }^{56}$

Perhaps of more practical import, an extensive public relations campaign was already well under way. The Board knew that the success of the transit scheme depended upon adequate financing, and that adequate financing in turn depended upon approval of the general obligation bonds that were soon to be submitted to the voters. Thus the public relations efforts were designed to convince the Bay Area voter that rapid transit in general, and the District plan in particular, were going to serve both his personal convenience and his economic interest. ${ }^{57}$ Public hearings and

50 Id. § 29038. Initially, BART will have to carry 210,000 people a day to cover operating costs. Hearings before the Assembly Interim Comm. on Transportation and Commerce, supra note 46 , at 7 .

51 CAx. PUb. UxII. CODE §§ 29038 (West 1965). See also id. § 28766.

52 Id. \& 29010.

$53 \mathrm{Id}$. § 28767. The einployed staff now includes a general manager, id. $\S \S 28830-35$, a controller-treasurer, a chief engineer, a general counsel and a director of information.

54 Id. $\S 28768$.

55 The Board hired Mr. John M. Pierce, the former California State Director of Finance under Governor Goodwin Knight.

56 The joint venture of Parsons-Brinckerinoff-Tudor-Becitel was employed on May 14, 1959 as General Engineering Consultant to the District. Financial consultant was Smith, Barney \& Co., investment bankers, and the law firm of Orrick, Dahlquist, Herrington \& Sutcliffe was to serve as bond counsel.

${ }^{.57}$ An employee of the District has called this campaign "a comprehensive aggressive 
technical liaison committees ${ }^{58}$ were set up in every major District community. A former Oakland Tribune newsman, Mr. Billy Ray Stokes, was appointed Director of Public Information, and a speakers bureau was established with speakers drawn from the San Francisco Junior Chamber of Commerce. In order to cast the District's message abroad, these young men were made "available immediately for noon and evening appearances before clubs and organizations."

This campaign met with considerable initial success in molding a favorable public response to BART. ${ }^{60}$ It was building toward a peak for the planned November 1960 bond election ${ }^{61}$ when the District received its first major setback-two of its five counties began muttering of secession. This unhappy development forced a postponement of the bond election until the question could be resolved and the boundaries of the District firmly set. ${ }^{62}$

Marin County, the smallest in the District and having an area of 520 square miles with a population of $146,820,{ }^{63}$ had always assumed that in order for its residents to travel to San Francisco by rapid transit, their

public information program on a daily basis." He states, "We have never turned down a single speech request in the district. We sometimes had a schedule of fifteen speeches a week. We believe that this was one of the effective parts of the program, presenting to the voters the alternatives they had.

"This was not a flashy, supercilious-type program, but the development of the facts, and complete lonesty of the fiscal implications and the need for the program." Hearings before the Assembly Interim Comm. on Transportation and Commerce, supra note 46, at 5 (testimony of Mr. Ed Sajor).

58 According to Mr. Sajor, supra note 57, these committees were composed of city engineers and planners, directors of public works, and traffic engineers. See note 61 infra.

50 Rapid Transit-An Inforamation Digest from the San Franctsco Bay Area Rapid Transit District, Feb. 1959, at 4 [hereinafter cited as Rapio Transit Information Digest].

60 For example, in Marcl 1959 the California State Automobile Association endorsed the District's plan as a promising way to imcrease the efficiency of the state's freewny system. In the same month, Harrison Salisbury called District efforts "a shining example of advanced thinking" in his New York Times series entitled "The Commuter Crisis." $I d_{\text {., }}$ March 1959, at 1.

61 See id., Feb. 1960, at 1: "Concurrent with a general speedup in overall planning to meet a November bond election deadline, the District within the next few months will hold a series of meetings in the five counties to review current engineering progress and route selection."

- -

"A series of well-publicized public presentations will be held throughout the District in centrally-located high schools in March." See also U.S. ADvisORY COMOM'N ON INTERGOVERMMENTal Relations, IntergovernMEntal Responsibilities for Mass Transportation Facitities and Services in Metropolitan Areas 37 (1961).

62 The vote was subsequently scheduled to take place at the Califorma priniary election in June 1962, Rapid Transit Inforacation Digest, Feb. 1961, at 1, and was then rescheduled for the general election in November of that year, id., April 1962, at 1.

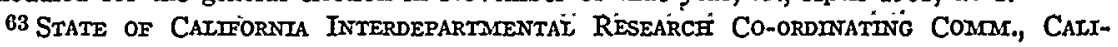
FORNIA StatistTCaI, ADSTRACT 1, 51 (1965). 
trains would have to pass over the Golden Gate Bridge. But after an extended controversy and conflicting engineering reports on the feasibility of adding a transit infrastructure to the bridge, a special panel of engineers concluded that the addition of transit facilities would place unpredictable and potentially dangerous stresses on the span and could measurably decrease its useful life. ${ }^{64}$ This finding led to the refusal of the bridge directors to allow BART on the bridge. Shortly thereafter the Marin County Board of Supervisors withdrew from the District. ${ }^{65}$

The other troubled county was San Mateo, some of wliose elected officials had been concerned about what they considered the high cost of the plan from the start. The county's 454 square miles and 444,387 people $^{66}$ were already served by a line of commuter trains to and from San Francisco, making it the only county in the District with such a rail service. ${ }^{67}$ When the county supervisors considered the actual cost of BART's plan and the travel facilities already available, they rejected the proposed system $^{68}$ and soon withdrew entirely from the District. ${ }^{69}$

Bloodied but undaunted, the District continued its efforts to win over voters in the three remaining counties-San Francisco, Alameda, and Contra Costa-in time for the coming bond election in November 1962. The campaign intensified in its last four months: ${ }^{70}$ innumerable speeches were made by the District staff; ${ }^{71}$ campaign materials depicting the ad-

64 San Francisco Chronicle, Aug. 1, 1961, at 1, col. 3.

65 See Rarid Transit Information Digest, April 1962, at 3. This withdrawal officially occurred on May 17, 1962. Interview with Stanton Thies, Deputy Director of Information, Bay Area Rapid Transit District, in San Francisco, May 5, 1967.

60 California Statistical ABstract, supra note 63, at 1, 51 .

67 Despite the claims of some officials, this railroad line is not the only such comnuter service in the West. Commuters can travel from Orange County into Los Angeles by rail.

68 San Francisco Chromicle, Dec. 20, 1961, at 1, col. 1. The Transit Research Foundation of Los Angeles has suggested that the District should have condemned the railroad's right of way and then taken over its commuter operations in San Mateo and San Francisco counties, but that fear of the pohtical power of the Southern Pacific may have deterred this "aggressive attack." City and Suburban Traver, Jan. 1962, at 10.

60 See Rapid Transit Information Digest, April 1962, at 1. San Mateo's secession occurred officially on April 12, 1962. Thies Interview, supra note 65 . The withdrawal of Marin and San Mateo Counties left the District representing an area of 1,512 square miles and a population of just over two million. Cartfornia Statisticar Abstract, supra note 63 , at 1, 51 (1965). Both Marin and San Mateo Counties were subsequently given their own transit districts by the state legislature. See CaL. PuB. UTIr. Code $\S \S 70000-$ 80019 (West 1965); id. App. 3 \$§ 1.1-14.3 (West 1965). Recently San Mateo County's "West Bay Rapid Transit District" was reported to be considering rejoining BART in some loose form of "partnership." San Francisco Chromicle, Feb. 8, 1967, at 1, col. 1.

70 See testimony of Mr. Ed Sajor, supra note 57, at 9.

71 Newsweek Magazine reported the preelection situation as follows: "[O]nce the design and financing plans had been completed, BART officials spent several years mobilizing public opimion for voting support on the bond issue. One local politician called the campaign 'a fool's errand ... . its chances of passing are 100 to 1.'", 
vantages of BART were distributed throughout the District; ${ }^{72}$ and more public hearings were held. ${ }^{73}$ These concentrated efforts proved successful, but only by the barest margin. Sixty per cent of the voters in the District had to approve the bond issue for it to be adopted; ${ }^{74}$ sixty-one and twotenths per cent did in fact approve it. ${ }^{75}$

The 792 million dollars in general construction funds ${ }^{76}$ which these bonds are now providing are the backbone of the District's financing, but there have been other appropriations made which have been vital to BART. Three years before the bond issue was passed, the State of California conditionally committed its Toll Bridge Authority to issue 115 million dollars in revenue bonds backed by bridge tolls to finance the construction of an underwater tube passing under the bay and linking the two eastern counties with San Francisco. ${ }^{77}$ These funds were to become available upon the approval of the District's overall plan by the voters. ${ }^{78}$ The funds were cleared for use by the California State Department of Public Works ${ }^{70}$

But BART president Adrien J. Falk, 80, former chairman of S\&W Fine Foods, enlisted the backing of such leading citizens as James D. Zellerbach, former U.S. ambassador to Italy, and Carl Wente, former Bank of America president. A professional eampaign staff was retained. And Falk, (General Manager) Stokes, and other BART officials embarked on a continuous round of speechmaking. "We didn't turn down a single request," Stokes recalls. "I gave as many as four speeches a day-breakfast, lunch, midafternoon and dinner." NewSWEEK, July 19, 1965, at 70.

72 According to BART's Deputy Director of Information, there was no general election mailing made to all registered voters. However, over the last five years, 400,000 copies of the District's map brochure have been distributed. Thies Interview, supra note 65 .

73 Rapid Transit Information Digest, June 1962, at 1.

74 See note 43 supra and accompanying text.

75 The final vote was 438,504 in favor of the construction bonds with 277,827 opposed. Thus, if out of the 716,331 voters, just 8,707 had ehanged their minds and voted against BART, the bonds would have been rejected. The statute setting up the required percentage of voter approval, CaI. PUB. UTII. CODE $\$ 29168$ (West 1965), was amended by the legislature a year before the election. The margin of approval needed was lowered from two-thirds to three-fifths of the qualified electors voting. Without this change BART's bond clection would have failed by over $5 \%$.

70 San Francisco Bay Area Rapid Transit Dist., Official Statement Relating to: $\$ 50,000,000$ General Obligation Bonds Series A, Nov. 21, 1963, at 7.

77 See RapiD Transit Inforacation Digest, June 1959, at 1 ; Id., July 1959, at 2, 4. Apparently a strong tidal fiow prevented this sort of tube's being constructed across the Golden Gate to Marm County once the Bridge was found to be unsuitahle for the addition of rapid transit tracks.

78 Cax. Sts. \& H'ways Cone $\$ 30775$ (West Supp. 1966). See RapID Transit InformaTION DIOEST, June 1959, at 1 .

79 See [1965-1966] San Francisco Bay Area RapID Transit Dist. ANN. ReP., note C;

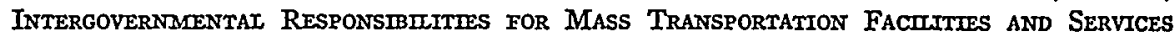
IN Metropotitan AREas, supra note 61, at 37. Because of some technical requirements in the original federal act granting consent to the State of Califorma to construct the Bay Bridge, Congress also had to approve this use of bridge tolls. The requisite Congressional approval occurred on February 20, 1960, with the passage of Pub. L. No. 86-388, 74 Stat. 5. Interview with Warren Marsden, Stafi Counsel, Bay Area Rapid Transit District, in San Francisco, Cal., May 5, 1967. 
after the November 1962 election, and final planning for the construction of the transbay tube began shortly thereafter. ${ }^{80}$ The federal government has also provided valuable assistance by granting BART over 8 million dollars to help in the development and testing of innovations in rapid transit planned by the District. ${ }^{81}$

\section{Taxpayer's Suit}

With these funds the Board of Directors was able to begin employing the personnel necessary for the actual construction of the system. The engineering firn initially hired as the District's consultant was instructed to begin full-scale design and construction plans; ${ }^{82}$ the Stanford Research Institute was employed to conduct sound and stability studies; ${ }^{83}$ and a contract was awarded to Advance Data Systems Corporation to determine the requirements for passenger administration and fare collection. ${ }^{84}$ But before the actual construction of BART could begin, the District had to face and overcone its second major obstacle-a taxpayer's suit aimed at halting the entire plan.

According to the statute creating the District, a taxpayer's suit challenging the issuance of bonds pursuant to the election could be brought within six months after the bond issue had been authorized. ${ }^{85}$ However, if the persons instituting the suit were acting "without probable cause," they would be hable for the resulting costs and damages "in an amount which will compensate the district for all the detrinent proximately caused thereby, or which, in the ordinary course of things, would be likely to result therefrom." ${ }^{386}$ A group of taxpayers headed by a city councilinan and a mayor-restauranteur from Alanieda County, a farmer from Contra Costa County, and a coin laundry operator from San Francisco County were apparently willing to subject theinselves to these consequences. ${ }^{87}$

This intrepid group alleged, anong other things, that BART had abused its discretion in the contracts it had awarded, that the preelection campaign was an improper expenditure of public funds in an effort to

80 As of May 1967, design and construction of the transbay tube were approximately $24 \%$ completed. Thies Interview, supra note 65 .

81 [1965-1966] San Francisco Bay Area Rapto Transit Dist. AnN. Rep., note B. As of June 30,1966 , federal grants received by BART amounted to $\$ 6,781,513$. Id. For additional federal funding, see note 105 infra and accompanying text.

82 This order was made by the District as of July 1, 1963. Thies Interview, supra note 65 .

83 Institute for Rapid Transit Newsletter, Dec. 15, 1963, at 24.

$84 I d$. at 25 .

85 CaL. Pub. Utri. Code §§ 29291-92 (West 1965).

86 Id. \& 29292.

87 Interview with Dewayne Boblitt, a plaintiff in the taxpayer's suit, in El Cerrito, Cal., Feb. 10, 1967; Thies Interview, supra note 65. 
mislead the voters, that the Directors had been overgenerous in their delegation of authority to their engineering consultants, and that this abdication had resulted in less than adequate safeguards on the continuing expenditure of public monies. ${ }^{88}$ After being deluged with pleadings over a six month period, the court first eliminated some of the allegations by calling them matters of law and then granting defendants summary judgment on them. Then, after hearing only the plaintiff's case at trial the court ruled that the bond election was valid, that the District's public information program had been a permissible expenditure, that plaintiffs were to take nothing by their complaint, and that defendants were to be awarded costs. ${ }^{89}$ No appeal was taken from this decision.

\section{Overland-Underground: Route Dispute}

With the only suit against them successfully concluded, the District was at last ready to begin actual construction. On June 19, 1964, BART's official groundbreaking ceremony took place outside the city of Concord; the Directors heard President Lyndon B. Johnson call their plan "a victory of vision for men who started twelve years ago to make it a reality."100 With this impressive sendoff, line construction began immediately. By mid1966, four and one-half miles of test track had been completed and landscaped, a three and one-half mile, twin-bore tunnel had been dug halfway through the Berkeley hills, and subways were going down and aerial lines were going up throughout the East Bay. ${ }^{01}$

However, BART's problems were far from over. The District had always prided itself in taking great pains to get the advice and consent of each local community on the shape the system would take as it passed through its territory. Where would the tracks run: down the center strip of a main shopping street, through an industrial sector, or on a line more convenient to residential areas? More important for the densely populated

88 Taxpayers Complaint To Prevent Illegal Expenditure of Funds, To Enjoin Sale of Bonds, To Prevent Signing of Illegal Contracts, For Declaratory and Injunctive Relief, To Compel Re-Payment of Money Illegally Expended, and Pretrial Statement of the plaintiffs in Osborne v. San Francisco Bay Area Rapid Transit Dist., No. 87332 (Super. Ct., Contra Costa County, Cal., June 10, 1963).

80 Osborne v. San Francisco Bay Area Rapid Transit Dist., No. 87332, (Super. Ct., Contra Costa County, Cal., June 10, 1963). These "costs" were the usual ones awarded in civil actions and included only reporters' and notaries' fees. The court did not mention the costs to BART brought on by the delay in construction until the suit could be litigated and disposed of. The "extra unanticipated cost" from inflation alone has been estimated at $\$ 9,794,000$ by the Legislative Analyst of the California Legislature. Letter from A. Alan Post to the late Senator Eugene McAteer, March 7, 1966, at 7, on file with the Californic Law Review.

90 Rapid Transit Information Digest, June-Aug. 1964, at 3.

91 See generally [1965-1966] San Francisco Bay Area Rapid Transit Dist. AnN. Rep. 
cities, would the tracks run at grade level, above ground on an aerial platform, or below ground in a subway? Minor disputes over proposed routes had been arising and subsiding almost since the District was established. ${ }^{92}$ Finally, the city of Berkeley precipitated the third major crisis for BART by blocking the District's planned elevated line and requesting a subway for much of the city route.

Civic leaders feared that Berkeley's Negro population would be placed in a walled ghetto by the elevated tracks ${ }^{93}$ and that the value of property adjacent to the tracks would be substantially depressed. Therefore, Berkeley requested a hearing before the District's Board of Directors pursuant to the procedure establisled in BART's enabling act. ${ }^{94}$ At this hearing, the city's mayor stated that if the District would place the line underground for a certain distance, Berkeley would pay the additional costs of such a subway. ${ }^{05}$ There was a lieated dispute over the magnitude of these additional costs, the city being certain that their proposed subway would cost less than wliat the District's engineers estimated. This dispute was resolved by the Board of Directors' decision to open both the subway and the aerial scheme to competitive bidding and then allow Berkeley to compare the actual winning bid for each before choosing whether it wanted to bear the extra cost of placing the line underground.

The city officials weiglied the results of the bidding and decided that the benefits to be derived from their subway plan would outweigh its extra cost to Berkeley residents. ${ }^{96}$ A referendum was held on this decision in October 1966, and the city's voters overwlielmingly ratified the subway

92 See, e.g., protests about the route by the mayor of the Alameda County city of Albany, Rapm Transit Inforatation Digest, Nov.-Dec. 1959, at 4, and those of the City Council of the Contra Costa County city of El Cerrito, id., July 1961, at 4.

03 "Elevated tracts, with trains traveling them at speeds up to 80 miles an hour, would create a ... 'Berlin Wall' dividing the city's Negro and white population, subway backers say, since some 90 per cent of Berkeley's Negroes live to the west and soutly of the right-of-way." San Francisco Chronicle, Oct. 3, 1966, at 18, col. 8.

94 CAI. PUB. UTII. CODE $\S \S 29039-45$ (West 1965). These sections provide that a city or county can have such a learing called by the District Board of Directors on "any proposal for fixing the location of facilities by the district." Id. $\$ \$ 29039,29040$. The learing need not follow techmical rules of evidence, id. $\S 29043$, but witnesses must be examined and cross-examined under oath, $i d$. $\S \S 29042-43$, and a conplete record of the proceedings nuust be kept, id. $\$ 29044$. After submission of the case the Board has thirty days to render a written decision "together with written findings of fact." Id. § 29045.

05 See Transcript of the Meeting of the Board of Directors of the Bay Area Rapid Transit Dist., May 14, 1964, at 2, 6-10 (testimony of Berkeley City Mayor Wallace J. S. Johnson).

00 Berkeley estimated that the plan would cost under $\$ 12$ million, while BART put the cost at over $\$ 20$ million. The Berkeley city manager's office estimated that "eventual yearly cost to the average homeowner-over a 30 -year period-would be $\$ 10.75$ for Berkeley's figures and $\$ 18.55$ for BART's." San Francisco Cluronicle, Oct. 3, 1966, at 18, cols. 5-6. 
plan and its concomitant extra tax burden. ${ }^{97}$ Thus BART was compelled to build Berkeley a subway; today it is over fifteen per cent completed. ${ }^{98}$

\section{Toward Takeoff}

Having hurdled these three major obstacles-the loss of two of the original constituent counties, the taxpayers' suit, and the Berkeley route dispute-BART has been able to move forward in 1967 with property acquisition, contract letting and route construction. However, the road ahead has not been cleared entirely.

Today the Directors are beset with serious financial problems: The money appropriated for the system in 1962 has proved insufficient to withstand inflationary pressures and construction delays, ${ }^{90}$ and there is a possibility that BART soon will have to ask the electorate for another bond issue. ${ }^{100}$ At the same time District personnel have been under fire for what

97 This election was held under a set of unique provisions conceived to meet the Berkeley problem and inserted with BART's support into its enabling act in 1965 as CAL. PUD. UTII. CODE $\$ \$ 29660-29740$ (West 1965). These provisions allow cities or unincorporated territories within the overall District boundaries to form, by resolution or petition, a "Special Service District" in order to accomplish just the kind of thing Berkeley was trying to do-change BART plans into a form more acceptable to the comnunity. The purpose of forning such a "Special Service District" is to incur additional honded indebtedness to finance its own schemes, see id. \& 29700 , and, if the bond issue fails to carry, the district can be dissolved just as easily as it was created, id. $\S 29740$.

Berkeley city officials were hoping for a mandate of $75 \%$ approving their subway, and were gratified and surprised at the $83 \%$ favorable vote the plan actually received. Interview with Mayor Wallace J. S. Johnson of Berkeley, in Berkeley, Cal., May 9, 1967.

98 Thies Interview, supra note 65.

90 In Septeinber, 1966, the BART staff estimated a total project cost overrun of $\$ 151,224,000$. Rapm Transit Inforamation Digest, Fall 1966, at 1-2, By the spring of 1967 it had been estimated by District personnel that the cost overrun could be held to as low as $\$ 88$ million, Oakland Tribune, Feb. 10, 1967, at 4, col. 1, or that the deficit could go as high as $\$ 160$ million, San Francisco Chronicle, April 28, 1967, at 1, col. 7.

100 BART personnel are less than optimistic about the prospects of getting such an additional bond issue approved by the electorate; they are looking to increased federal and state financial aid in order to make such drastic action unnecessary. Thies Interview, supra note 65 .

The Mayor of San Francisco has stated that he is "convinced the voters of the threecounty district would not approve another bond issue." San Franciseo Chronicle, April 5,1967 , at 5, col. 6 . Among the suggested alternatives are (1) an increase in auto tolls on the Bay Bridge or in gasoline taxes and auto hicense fees with the increase earnarked for BART, (2) increased federal funding, or (3) econony cuts in the system itself. According to BART staff personnel, such changes could include finishing stations to only a six-car length, instead of the originally planned ten-car length, eliminating landscaping, and skipping some planned stations. San Francisco Chronicle, Feb. 24, 1967, at 1, col. 1.

Various bills to ease the financial pressure on BART were introduced in this session of the California Legislature. See, e.g., S.B. 775, 776, Cal. 1967 Sess, (introduced by the late Senator McAteer of San Francisco). None was passed. San Franciseo Chronicle, Aug. 4, 1967, at 1, col. 1; San Francisco Examiner, Aug. 7, 1967, at 7, col. 1. 
some critics regard as lack of imagination in planning and design, and even lack of general management ability. ${ }^{101}$

In spite of these difficulties BART has been able to sell its general obhigation bonds at a favorable interest rate, ${ }^{102}$ and recently the District was aided by a substantial capital construction grant from the federal government. ${ }^{103}$ More than half of the system is now under contract, ${ }^{104}$ some passengers will be carried in $1969,,^{105}$ and the District will be fully operational by $1971^{106}$

\section{III}

\section{HISTORY OF THE LONDON TRANSIT SYSTEM}

The story of London's public transport system has often been told. ${ }^{107}$ The following account concentrates upon the subway system.

101 Two consulting architects resigned from BART in September 1966 because of what they termed "lack of concern for regional planning and good architecture." San Francisco Chronicle, Oct. 25, 1966, at 4, col. 1. The general manager of BART interpreted their protest as founded upon a "view that architects should be given equal status with engineers in the design of the transit system." San Francisco Chromicle, Nov. 8, 1966, at 4, col. 3. A local chapter of the American Institute of Architects added fuel to the fire by citing what it called BART's "lack of design and thoughtful planning." San Francisco Chronicle, Sept. 29, 1966 , at 1, col. 1 .

The volume of criticism reached a peak when a major San Francisco newspaper ran a series of front page articles by Allan Temko, their "Architectural Correspondent." Under the headlines of "How BART Is Botching It All," "BART Needs Big Shakeup," "The Butchery of BART's Stations," and "BART's Financial Hocus-Pocus," Temko attacked "blundering management and insensate engineering" in a thorough indictment of the entire system. Temko, A Critical Essay, San Francisco Chromicle, beginning Sept. 28, 1966, at 1, col. 1 ; id., Sept. 30, 1966, at 1, col. 2 ; id., Oct. 3, 1966, at 1, cols. 1-2; id., Feb. 10, 1967, at 1, cols. $1-2$; id., Feb. 11, 1967, at 1, cols. 2-3. B. R. Stokes, general manager of BART, has rephed in kind, calling Temko "an arrogant critic who could learn the facts but who has no interest in doing so," and branding his "continual harping" a disservice to the public because "it makes our job more difficult in negotiations and it has an effect on bond interest rates." San Francisco Chronicle, Feb. 11, 1967, at 1, cols. 2-3.

102 According to District records, the following sales have occurred:

\begin{tabular}{lccr} 
& & Net Interest & \multicolumn{1}{c}{ Date } \\
Series A & Amount & Cost & $12 / 10 / 63$ \\
Series B & $\$ 50$ million & $3.36990 \%$ & $9 / 15 / 64$ \\
Series C & $\$ 60$ million & $3.45560 \%$ & $7 / 14 / 65$ \\
Series D & $\$ 70$ million & $3.38374 \%$ & $11 / 17 / 65$ \\
Series E & $\$ 70$ million & $3.58780 \%$ & $10 / 27 / 66$ \\
Series F & $\$ 50$ million & $3.77400 \%$ & $2 / 16 / 67$
\end{tabular}

103 This grant of $\$ 13.1$ million was made under $\$ 3(a)$ of the Urban Mass Transportation Act of 1964, Pub. L. 88-365, 78 Stat. 302, for capital funding purposes.

104 Thies Interview, supra note 65.

105 [1965-1966] San Francisco Bay Area Rapid Transit Dist. Ann. Rep. 2.

106 Id. at note $\mathrm{D}$.

107 E.g., T. Barker \& M. Robbins, 1 A History of London Transport (1963); H. 
As the capital city of Great Britain, London was the hub of a national steam railway system during the nineteenth century. In 1855 a select committee of the House of Commons, aware of the need to coordinate internal traffic in the metropolitan area, recommended a system connecting the railway termini in London. Other transit projects were initiated during the same period. Construction began on a steam railway connecting Paddington Station with Farringdon Street in the city. The railway, completed in 1863, was laid in open cuttings where possible and otherwise underground. In the same year a select committee of the House of Lords approved the concept of underground railways and recommended construction of the "Inner Circle," an underground urban ring which encloses a considerable area of central London. The Inner Circle was completed in 1884.

The Inner Circle, although underground, was not constructed as a typical London tube. The tube was a later development consisting of sets of railway tracks laid in an iron-lined, deep-level tunnel in the London clay. Electrification made this form of construction possible, the first stretch of line being opened in 1890 . Forty years later the route totaled one hundred thirty-two miles, a considerable, if not vast, expansion. The underground system was then largely under the control of a group of private companies under Lord Ashfield. ${ }^{108}$ This group also controlled most of the omnibus systems.

The transit developments after 1930 were preceded by numerous official inquiries and investigations. ${ }^{100}$ One theme that ran through these reports was the need to place all transport services of the metropolis under the control of one authority, separate from existing central or local governmental bodies. A small, expert, ad hoc public authority, operating under the control of the Ministry of Transport, was generally envisioned as the proper unit of management.

The London and Home Counties Traffic Advisory Committee was

Morrison, Soctalisation and Transport (1938); Davies, The London Passenger Transport Board, in Pubutc Exterprise (W. Robson ed. 1937). See also A. Wrottesley, Famous UNDERGROUND RAIIWAYS OF THE WORID (rev, ed. 1960).

108 For a detailed account of the preconsolidation London Underground Group of Companies,-comprised of the Metropolitan District Railway, the London Electric Railway, the City and South London Railway, and the Central London Railway-see J. Thomas, HandLING LONDON's UNDERGROUND TRAFFic (1928). These companies handled their profit distributions by a system known as the "Common Fund," whereby the balance remaining after meeting expenses and fixed charges was pooled and shared on a pro rata basis. Id. at 2 .

109 Herbert Morrison refers to eight major reports between 1905 and 1927. H. MoRRISON, supra note 107, at 25, 26. 
established in 1924 and in a report to the Minister of Transport ${ }^{110}$ in 1926 said:

No lasting solution of the London passenger transport problem can be secured so long as the present competitive methods are pursued. It is only by the elimination of all wasteful, uneconomic and unnecessary competition between the various transport agencies, that it will be possible for any considerable improvements to be effected, particularly in the way of the construction of new underground or surface railways. ${ }^{111}$

In 1927 this Committee published a scheme for coordinating passenger transport facilities in the London area. Their plan did not envision transferring ownership from existing proprietors, but rather estabhishing a means for regulating fares, services and resource allocations.

The Traffic Advisory Committee recommended the creation of a private monopoly to control London's transport system. The Labour Party opposed the idea and the Parliamentary bills to promote it failed to reach the statute book before the fall of the Conservative Government in 1929. Herbert Morrison became Minister of Labour in the Labour Government and produced new proposals which culminated in the London Passenger Transport Bill of $1933 . .^{112}$

\section{A. The London Passenger Transport Board}

In July 1933, the London Passenger Transport Board assumed control over London passenger traffic, including all underground railways and tubes, the tramway system, the omnibuses and many long distance coacl companies. Lord Ashfield, chairman of the former private transport group, was made chairman of the seven-member Board. Chairmen and members were appointed by "appointing trustees"-a very curious device sharing with the mule no pride of ancestry or hope of progeny. ${ }^{113}$ These appointing trustees held the following offices: chairman of the London County Council, a representative of the London and Home Counties Advisory Committee, chairman of the Committee of the London Clearing Bankers,

110 London \& Home Counties Traffic Advisory Comparan, Report, cited in Morrison, silpra note 107, at 32 .

111 Id. at 32-33.

112 London Passenger Transport Act of 1933, 23 \& 24 Geo. 5, c. 14.

113 Under Morrison's original Bill, members of the Board were to be appointed by the Minister of Transport. H. Morruson, supra note 107, at 161. This would have enabled Parliament to hold the Minister responsible to some extent for the actions or inactions of the Board. The device of "appointing trustees" effectively isolated the Minister from all responsibility and made it almost impossible for Parliament to criticize the Board. Both before and after this experiment, members of other public boards in Britain were usually appointed by the appropriate Minister of the Crown. 
the president of the Institute of Chartered Accountants of England and Wales, and the president of the Law Society. It has never been clear why these officials were particularly suited to select the managers of London's transport system. ${ }^{114}$ The members of the Board first appointed included Iord Ashfield's chief assistant, a union official, a director of the Bank of England, and a former chairman of the London County Council.

The London Passenger Transport Board was under the duty to provide an adequate and properly coordinated system of passenger transport for a 1,986 square mile area containing $9 \mathrm{~T} / 2$ million people. The various services were to function as an integrated unit with fares and charges regulated to produce sufficient income to cover expenditures and liabilities, including the payment of interest on the interest-bearing stocks of the London Board. The Board had a virtual monopoly over rail services within 1,550 square miles of its area. The long distance railways which helped to alleviate suburban traffic congestion were not actually under the Board's jurisdiction, but a working cooperation was achieved. Later, in 1947 , these railways were nationalized. ${ }^{115}$

Because of political necessities of the time, the London Passenger Transport Board was expressly prevented in several ways from competing with private enterprise. It could not carry goods by road, manufacture its own railway rolling stock or buses, operate garages for the motoring public, or operate a taxi service. ${ }^{116}$ Fares were subject to approval by the Railway Rates Tribunal. ${ }^{117}$ Yet, within its limits, the London Board was almost free from Parhamentary control.

\section{B. Nationalization of Transport}

In 1947 the governing structure of the London transit system was again changed when the Labour Government nationalized all public transport facilities. Subsequent changes of government and amendments to the legislation of 1947 have resulted in additional alterations during the last twenty years. The national railways have become more and more uneconomic as the British public has turned increasingly to the automobile for intercity transportation. In an attempt to respond to this evolution as it affected London transportation, the Transport Act of 1962 was enacted. ${ }^{118}$

114 These appointing trustees had to fulfill the same task as the elected local officials did under the BART statute: appoint the actual directors of the system. See text accompanying notes 35-37 supra.

115 Transport Act of 1947,10 \& 11 Geo. 6, c. 49, sched. 15.

116 For a discussion of BART's powers see text accompanying notes 41-49 supra.

117 The Railway Rates Tribunal indirectly, therefore, controlled the provision of new transit facilities since fare revenues had to cover expenditures. See note 123 infra and accoinpanying text.

118 Transport Act of 1962,10 \& 11 Eliz. 2, c. 46, § 15 . 
Under the Act, nationalized transport facilities are controlled by four boards: the British Railways Board, the London Transport Board, the British Transport Docks Board, and the British Waterways Board. The chairman of each board is appointed by the Minister of Transport, and the other menibers are appointed by the Minister after consultation with the chairman. ${ }^{119}$

The jurisdiction of the British Railways Board includes part of London, ${ }^{120}$ and the Act requires the Railways Board to coordinate its railway services in London with the services provided by the London Transport Board. ${ }^{121}$ The London Board's responsibility covers public passenger transport services including all buses and subways but excluding railways.

Each board has power-subject to ministerial approval-to construct, manufacture, produce, purchase, maintain and repair anything required for its purposes. They also have power to enter into contracts, acquire land, ${ }^{122}$ dispose of their property, train and educate their employees, and do all other things necessary to carry on their business. Each board niust conduct its operations so that yearly revenues will cover yearly expenditures properly chargeable to revenue. ${ }^{123}$ Within prescribed limits each board may borrow nıoney on a short term basis from the Minister or, with the consent of the Minister, from any other person. Each board may also borrow from the Minister for long term capital purposes. In addition, the Minister may make grants to the Railways Board to meet its deficits.

In the tradition of other nationalized industries in Britain, the Minister has the power to give directions to a board concerning the exercise and performance of functions which affect the national interest. Also, in framing and carrying out proposals involving substantial outlays from the capital account, a board is required to act according to policies which are subject to approval by the Minister. Therefore, if the London Board and the Minister agree on major developments of the transport services-

110 The Railways Board has a chairman, one or two vice chairmen and not more than sixteen nor less than ten other members. The London Transport Board has a chairman, a vice chairman, and not more than nine nor less than four other members.

120 In South London particularly, the Railways Board supphes an important service to commuters from the suburbs to the urban center.

121 The statutory duty of the London Transport Board is to provide an adequate and properly coordinated system of passenger transport for London having due regard for the efficiency, economy and safety of the system.

122 The Minister's authority is required for compulsory acquisition of land. Transport Act of $1963,10 \& 11$ Eliz. 2, c. 46,815 .

123 This is usually described, not quite accurately, as a requirement to break even. In London proposals for changes in fares are subject to approval by an independent tribunal. Transport Act of 1962, 10 \& 11 Eliz. 2, c. 46, $\$ \$ 44-47$. 
such as the construction of a new subway-no other authority is needed. But the Minister has ample power to prevent the board from proceeding if he disapproves their proposals.

\section{IV}

THE VICTORIA IINE AND THE CONSTRUCTION

\section{OF RAPID TRANSIT}

London has had no new tube for sixty years. ${ }^{124}$ In 1949 a working party was established, comprising members of the Railway Executive and the London Transport Executive under what was then the central body of nationalized transport, the British Transport Commission. The working party was to report on necessary railway developments to meet London traffic needs. Of the proposals suggested, the Commission recommended the plan for a new underground segment to the London Transit system, the so-called Victoria Line. ${ }^{125}$ In 1956 Sir John Elliot emphasized the great changes in the London metropolitan area since the last new line had been opened in 1907.26 The population of London had grown, commuting had increased, and peak hour traveling had become a serious problem. The Victoria Line would serve the West End of London which, having become a center of business and commerce as well as shopping and amuseinent, was inadequately served by the existing tube lines. The northeast suburbs would also be serviced by the Victoria Line.

This new hine would not only serve new population centers but would also reheve congestion in existing transit services. In 1956 it was estimated that the new tube would carry peak-hour densities of 16,000 passengers an hour in one direction and would cost about fifty million pounds. Operating expenses for a service consisting of thirty-two trains an hour in peak periods were estimated at over one million pounds a year. However, since the line would siplion traffic away from existing lines, experts estimated that the Victoria Line would involve an annual working deficit of only a quarter of a million pounds. Including interest payments on the borrowed capital, the total annual deficiency was expected to be about two and a quarter million pounds. At that time the annual fare revenue in the London area was nearly a hundred million pounds. After weighing these considerations, Parliament passed a bill in 1956 authorizing construction of the Victoria Line.

124 The following account of the pre-1956 history of the new line is based on an article by Sir Jolnn Elliot, then chairman of London Transport Executive in 26 INsT. OF Transport J. 318 (1956).

125 The Victoria Lime would run from Brixton in South London to Victoria Station, crossing the river Thames at Vauxhall, then north to the railway stations at Euston and King's Cross and thence to Walthamstow in the northeast of London.

126 See Elliot, supra note 124. 
In 1963, after the new nationalized transport structure had been introduced by the Transport Act of $1962,{ }^{127}$ Parliament passed a private London Transport Act empowering the London Transport Board to acquire land and construct works and conferring additional powers on the Board. Subsequent London transport acts have incorporated many of the provisions of the 1963 Act. $^{128}$

To understand the provisions of these statutes, one must understand the political realities of the transportation situation in London. There are three principal public bodies in addition to the London Transport Board concerned with the promotion of transport projects in London-the Ministry of Transport, the Greater London Council and the British Railways Board. These four public bodies work through coordinating committees. The Ministry of Transport is effectively the senior member of this group, and its approval must be obtained for capital works projects before a private bill is introduced in Parliament.

When Ministry approval has been obtained, "referencing" is the most time-consuming task remaining before the bill can be introduced into Parliament. Referencing involves ascertaining land ownership rights likely to be affected by the construction and compiling a book of reference with maps. This procedure may take several engineers several months. The plan which emerges becomes the plan deposited in Parliament with the bill.

Despite the general powers bestowed on the London Transport Board by the Transport Act of 1962, the Board-in initiating separate work projects-currently relies primarily on private acts of Parliament coupled with general powers conferred by earlier legislation. ${ }^{129}$ Private acts may be sponsored by many public authorities in Britain. Section 17(1) of the Transport Act of 1962 provides that "[e] ach Board may, with the consent of the Minister, promote Bills in Parliament and may oppose any Bill in Parliament."

Private bill procedure is old and much more complicated and time consuming than public bill procedure. If a private bill is opposed-and many public and private interests may wislı to oppose private bills-the procedure may be lengthy and expensive. Great effort is therefore made before the bill is introduced into Parliament to meet objections in the hope that the Bill will not be opposed.

127 See text accompanying notes 118-23 supra.

128 The Act of 1964 incorporated twelve sections of the 1963 Act, the Act of 1965 incorporated fourteen sections, and the Act of 1966 incorporated thirteen sections. The 1963 Act authorized works resulting from a change in the route of the Victoria Line; the Act of 1964 was for miscellaneous works; the Act of 1965 was for a new line underneath the Thames linking existing stations; and the Act of 1966 was for an extension of the Victoria line to Brixton.

129 E.g., Railway Clauses Consolidation Act of 1845, 8 \& 9 Vict., c. 20; Land Clauses Consolidation Act of 1845, 8 \& 9 Vict., c. 18. 
The advantages of proceeding through a private bill are numerous. Land can be acquired under the bill itself rather than by a separate proceeding, and interference with other property rights can be authorized simultaneously. If the general powers in the Transport Act of 1962 were used, a number of special approvals and consents would have to be obtained; but by proceeding by private bill, all these matters can be discharged at once.

However, there are also disadvantages to proceeding by private bill. Parliamentary procedure governing private bills is a labyrinth of detail. ${ }^{130}$ After the bill has been passed by Parliament, the approval of the Ministry must again be obtained to implement the project as detailed in that bill because the Ministry is the source from which capital moneys are borrowed.

The London Transport Act of 1966, directing the London Transport Board to provide transport in the London area, is an excellent example of private bill procedure. ${ }^{131}$

130 For every private bill, a petition signed by the promoters must be deposited in the House of Commons and the House of Lords with a printed copy of the proposed bill annexed. Before the bill is presented, standing orders require certain procedural steps to be taken, notices served, and plans deposited. In the House of Commons, a private bill is presented by being deposited in the Private Bill Office. "Examiners" determine whether standing orders have been compled with. The first reading of the bill is formal. On the second reading the House affirms the general principle or expediency of the measure, but this approval is conditional and subject to proof of the allegations of fact set out in the bill. Normally this proof and the expediency of the bill are left to the committee stage. After the second reading the bill is sent to a committee and in doing so the House may give an instruction for the guidance of the committee to insert definite provisions in the bill, or to omit definite provisions, or to make further inquiry into certain matters. If a bill is unopposed, it is referred to a committee of five members of the House; if opposed, to a committee of four members having no local or other personal interest in the bill. A printed copy of every bill must be deposited with the Treasury and other government departments. Departments may make reports on the bill to the committee. In the case of an unopposed bill, it is the committee's special responsibility to ensure that the interests of the publlc are effectively cared for and that the bill conforms with standing orders. The promoters have to present sufficient evidence to satisfy the committee as to the propriety of the bill. In the case of an opposed bill, the committee stage somewhat resembles a judicial proceeding. Counsel are normally briefed and appear, examine witnesses, and cross-examine the witnesses of the other side. The proceedings are open to the public. Opposition may be limited to particular elauses of the bill or may be more general. The committee deliberates in private at the close of the argument and makes a report, perhaps amending the bill, to the House which then "considers" the bill. The House may itself amend it and then give it a third reading. The bill then passes to the House of Lords. If the Lords amend the bill, it must return to the Commons, for their approval or disapproval of the amendments. See generally, T. Ersinine May, Treatise on the Law, Prinieges, Proceedings, and Usage of ParlisMENT (17th ed. 1964).

131 The preamble of the Act recites that the limited period for the condemnation of certain lands should be extended, that the Board should be empowered to construct works authorized by the Act and to acquire the lands referred to in the Act, and that plans, sections, and a book of reference have been deposited in Parhament. The preamble also repeats the statutory duty placed on the Board by the Transport Act of 1962 . 


\section{CONCLUSTON}

The transportation problems facing the Bay Area and the London Metropolitan Area are fundamentally similar. Both are problems of commuting into and within urban areas of increasing population. In London the public transport system is mucl more highly developed than in the Bay Area, and, althougl crossing the river Thames presents certain physical problems, these problems are not comparable with those of crossing the Bay. In both regions the need for new public transport facilities is recognized as acute, and the increase in private automobiles accentuates rather than diminishes the problem.

Both regions are trying in similar ways to lure the traveler away from his automobile. This will be easier in London because the public transportation system is more extensive and convenient, and the Londoner does not consider a car quite so vital to complete personal liappiness as does the Californian. It is therefore quite possible to encourage London automobile drivers to part with their vehicles for the day at a large number of outlying Underground stations. BART also hopes to make this the accepted custom for Bay Area commuters, especially for those wlio live beyond the Berkeley liills. ${ }^{132}$ However, the internal transportation system

Part I of the Act incorporates certain provisions of the lands clauses acts. Part II authorizes the Board to make and maintain the work described therein, to open the surface of certain streets, and to block and discontinue a specified footpath. It then incorporates seven sections of the London Transport Act of 1963. These seven sections relieve the Board froin certain liability respecting roads, make general provisions as to the mode of construction, require plans and sections to be approved by the Minister, make provisions about the use of electrical power, require the Board to compensate in certain special cases in addition to the compensation provisions of incorporated acts, empower the Board to make test borings for subsoil investigation, and entitle the Board to use existing sewers for removing water. This section of the Act also incorporates one section of the Act of 1965 empowering the Board to underpin louses near their works.

Under Part III of the Act the Board can enter upon, take, and use lands delineated on the deposited plans and described in the deposited book of references. The Board can also acquire subsoil or easements in certain delineated cases. Three sections of the Act of 1963 are incorporated into Part III of the Act. These sections empower the Board to enter onto land in order to survey or value it, and to receive grants of easements, but forbid the Board from entering upon, taking, or using any cellar or vault not referenced except by separate agreement.

The Act also incorporates three sections of the Act of 1964 which deal with the acquisition of portions of certain properties, the disregard of recent improvements and property interests, and the extinction of private riglits of way over acquired land.

Part IV of the Act contains several protective provisions, both directly and by incorporation. The purpose of these provisions is to ensure that the works undertaken do not adversely affect other public works such as postal lines. The provisions frequently require consultation with local authorities before action is taken. Often the express consent of the local authority is required, but if consent is withheld the dispute must be settled by arbitration.

132 Initially 4,900 parking spaces are to be constructed beyond the Berkeley hills in Contra Costa County, with the facilities at Concord and Pleasant Hill being planned as the two largest in the entire District. Thies Interview, supra note 65. 
in the Bay Area, along with its singular geography, does not offer the same opportunities for receiving the concentration of incoming commuters from a relatively large number of starting points; and BART will also be faced with the formidable task of convincing the California driver that he will be better served by a public machine than by his private one. ${ }^{133}$

In both regions, public authorities have proved reluctant to interfere directly with the traveling habits of their communities. Limitations on parking time and the introduction of parking meters are mild devices indeed with which to change a businessman's commuting liabits. In London, the possibility of excluding certain classes of motorists from certain city areas, while much debated, is both technically and administratively difficult. In the Bay Area such legislation is probably politically impossible today, at least until some deadly crisis of panic or air pollution awakens the urban public to the need for such regulation.

Both regions visuahize the basic problem as moving people where they want to go, rather than as overall regional planning. The mandate of the London Transport Board or the Rapid Transit District is to establish a transportation system, and whether this system incidentally affects regional hiving patterns and industrial or service centers can be of no more than peripheral concern to its operators. If this is to be otherwise, and if the technical designers, construction engineers, and business managers of the transit operation are also to be urban planners and research sociologists, the California State Legislature or the British Parliament must enlarge their statutory authority. Unless and until such a change is made, it is as futile to rail at the transportation specialists for not being astute planning experts as it is to objurgate the moon for not being green clieese. ${ }^{134}$

133 For a colorful dissenting view on the value of rapid rail transit to today's freeway commuter, see Moskowitz, Living and Travel Patterns in Automobile-Oriented Citics, Traffic EngrneerIng, March 1963, at 13-14: "[My neighbors and I] go to work by car, at the time we want to go, and the longest it takes any of us is twenty four minutes. ... As a civil engineer who majored in railroad engineering, $I$ have been trying to figure out where I would lay a railroad that all of us could ride, if we were unhappy about driving." In discussing a proposal to spend his auto-use taxes on constructing a rail transit hine, Moskowitz states, "It is rumored that this imaginary single-track railroad would be able to carry 40,000 people in one hour. I cannot imagine where these 40,000 people would come from or go to, or what this railroad would be used for during the rest of the day, but I do know that I would not be one of them." Id. at 13-15. See also A. LAwo \& R. SOBERman, Urban RaIt Transit: Its Economics and Technology 5, 107 (1964); J. Mexer, J. Katn \& M. WoHt, The Urban Transportation Problem 102-07, 250-51 (1965).

134 See Temko, A Critical Essay, San Francisco Chronicle, Sept. 30, 1966, at 1, cols. 2-3: "'we are not regional planners,' protests supple B. R. Stokes general manager of the Bay Area Rapid Transit District. . . Y Yet the 75-mile system is undeniably a unique instrument for rational regional development in the counties bordering the Bay. . . [S] urely BART could be expected, as the only agency possessing so broad an overview of the region and so immediate an opportumity for action, to assume a moral responsibility 
The London and San Francisco experiences indicate that the kind of body created to govern a proposed public rapid transit system vitally affects the planning, construction and operation of that system. Further, the authority established to control the transit system tends to mirror both the strengths and flaws of its parent body.

The principal structural difference between the London Transport Board, which governs London public transportation, and BART, which is responsible for constructing San Francisco Bay Area rapid transit, is obvious. The American system is, in terms of elections and votes, far more democratic than the British. It is not a tradition of British government for sovereignty, in any general sense, to reside in the people. The British Constitution is based on the historical conception that the exercise of sovereignty is the function of the Sovereign. The fact that her Ministers are popularly elected officials who sit in Parliament and are responsible to the people's representatives for their conduct of public affairs does not mean that the British constitutional tradition puts the people above Ministers of the Crown. Consequently, a properly constituted government is expected to govern without seeking the approval of the people on specific decisions; the wliole notion of referenda, initiatives and other special elections is alien to the philosophy of British government.

The American practice of requiring popular approval of bond issues and other similar practices is not only a product of a different, more democratic plilosophy of the state; it is also a convenient tool for limiting major expenditures to popularly ratified public projects. The necessity of gaiming public approval for undertaking and financing public projects marks a fundamental difference between the two systems.

The British public would find it difficult to force a transit system underground as the voters in Berkeley did. Some parts of the London "tube" are in fact overground. Sometimes this is because that system at its peripheries runs through rural areas; sometimes it is just because it was constructed overground many years ago. The British would regard it as very odd if the decision whether a new part of the system should be underground or overground were put to the electorate of Lambeth or Chelsea property taxpayers, or if it were necessary at any point in the decision making process to mount a public relations campaign such as BART launched. ${ }^{135}$ In Britain there might be local inquiries, public meetings, or discussions in the local and national press. There might be consultation at many levels and private pressure groups seeking to influ-

for large-scale planning." Id. at 6 , col. 1 . It is difficult to discern any "moral" mandate in BART's enabling legislation other than its duty to provide "an adequate, modern, interurban mass rapid transit system." CAI. PUB. UTII. CoDE $\$ 28501$ (West 1965).

135 See notes 57-60 supra and accompanying text. 
ence the decision. But the decision itself is made by the public authority and never depends on the outcome of an election. ${ }^{136}$

London has had something hike a regional government for many aspects of public transportation for nearly forty years. Like its public predecessors, the London Transport Board consists of members appointed by the central government. ${ }^{137}$ The San Francisco Bay Area is now considering the possibility of some form of regional government. The body currently directing the construction of BART is the Bay Area Rapid Transit District. In contrast to the London Transport Board, its board of directors is appointed by elected local representatives. Therefore, there is a major difference between the proposed Bay Area regional government and the London regional government concerning relative strength of the local authorities vis-à-vis central authorities.

British central government departments are very strong. When the London municipal government was reorganized, approximately 100 local authorities were reduced to 34 . Some of the most powerful local authorities in Britain disappeared in the process, including the London and Middlesex County Councils-bodies representing two highly populated urban areas. It seems politically impossible that the State of California would be able or willing to exercise the same degree of compulsion over the cities and counties of the Bay Area. Government is perhaps as powerful in the United States as in Britain, but its authority is mucl more diffused. This diffusion of authority is not attributable to the great difference in the size of the two countries, for political authority is more diffused in the State of California than it is in the British Isles. It is attributable to the histories of the two countries, to their institutional traditions, and to their relative economic positions.

Local authorities urging their own case are commonly regarded in Britain as special pleaders. If their requests can be met by central departments without either mfringing departmental policy or adversely affecting

136 of course, occasionally voters may influence specific government action by electing an official who shares their views. Thus in Birmingham and elsewhere today the question of the system of state education to be adopted is an important issue of the political campaign. However, this debate is far removed from a decision whether a particular school should be built in a particular place, or whether a transit track should run above or below ground. That decision is taken jomtly by the appropriate local authority and the government department.

137 Labour Party policy on the shape of nationalization used to be much argued within party ranks. There were those who hoped that nationalized industries would be managed by those who worked in them-that is, some form of syndicalism or workers' control. But London's bill for the reorganization of London Transport in 1929-30 contained the principle of outside appointment, and those appointed were to be chosen on the basis of their professional and techmical expertise. This externally imposed management became the pattern followed in all the nationalization acts of the Labour Government of 1945-1951. See notes 118-23 supra and accompanying text. 
the interests of other public authorities, they will be heard sympathetically. In this sense, the system is flexible and responsive to local conditions. But departments do not hesitate to overrule local wishes if wider interests are involved or if more general issues are considered paramount. The center of gravity of Britisl political power is in the departments, not in the localities.

The British scheme for regional transportation as illustrated by the London Transport Board would seem more efficient than the Bay Area scheme as illustrated by the Bay Area Rapid Transit District. This is primarily because the British system is not so bound by the necessity for public approval of its projects. Nonetheless, it seems that both the Victoria Line and the Bay Area Rapid Transit System, conceived im 1949, are in the early stages of construction in 1967. In neither case is the story one of rapid action. It will be twenty years from the initial recommendations before tangible results are realized from either system.

In California this delay can be attributed in part to administrative delay caused by restrictions built into the Bay Area Rapid Transit District's democratic structure. ${ }^{138}$ In Britain, on the other hand, the lag should not be attributed to administrative delay. It has been caused far more by lack of construction funds. One of the most striking differences between the United Kingdom and the United States is the extent to whicl, in the former, capital investment control exercised by the central governnent dominates the planning of public works. General shortages of labor and materials lead almost inevitably to a system of priorities across the whole public scene, and these priorities affect the private sector both directly and indirectly. The transit project in London competes with other public and private projects for the limited resources. Hospitals, gas and electricity, schools, defense, factories and offices all have clamant demands, and the resources of the Britislı public authorities are more limited than their American counterparts.

Arguments about nationalization, socialization, governmental intervention, and individual freedom will always be advanced by all those affected by government action, as well as by those who have the responsibility for providing the public with necessary services. Most of these

138 At least one influential critic in California feels that the democratic obligations in BART's statute are unduly restrictive. See letter from A. Alan Post sulpra note 89, at 24-25:

The District should explore the possibility of laving its District Act anıended to strengthen its ability to act with expedition in its relationships with local government units within its jurisdiction. . . There are nunerous agreements yet to be obtained and, despite the generous efforts of the District . . . to achieve agreement with local governments, the progress in many instances has been slow. The District should now be strengthened and consideration should be given to renoving from the District Act the unusually restrictive hearing requirement and perhaps also remove the unusually restrictive condemnation requirements. 
arguments can be and are advanced in opposite directions. The primary private interest is in speedy travel. However, when so many have that interest, and seek energetically to promote it, the result is congestion. It is difficult to see how this private interest can be other than self-defeating; and so, in terms of classical economics and preclassical politics, the case is made for effective and expert public intervention.

The most limited justification for intervention is that public authorities can do what private interests will not or cannot do. The degenerate condition of our cities makes public intervention alınost inevitable. Beyond that, effective public intervention is inevitable if we are one day to create cities which are more than just endurable, cities which are actually pleasant places in which to live and work and travel. ${ }^{130}$ That this sounds utopian is the measure of our present predicament.

130 See the admirable statement of purpose in the BART statute itself: "[T]he prosperity of the entire Bay area will depend upon the preservation and enhancement of its urban centers and subcenters; .. sustaining these centers and subcenters as concentrations of employment, commerce, and culture, in turn will depend upon providing an adequate, modern, interurban mass rapid transit system." CAL. PUB. UTII. CODE § 28501 (West 1965). 